\title{
PENGARUH PENERAPAN PEMBELAJARAN PETA KONSEP TERHADAP PEMAHAMAN KONSEP KOLOID SISWA KELAS XI SMAN 2 MATARAM TAHUN AJARAN 2013/2014
}

\author{
Monica Ayu Chandrai ${ }^{1}$, Aliefman Hakim ${ }^{2}$, Eka Junaidi ${ }^{3}$ \\ ${ }^{1}$ Alumni Program Studi Pendidikan Kimia FKIP Universitas Mataram \\ ${ }^{2}$ Program Studi Pendidikan Kimia FKIP Universitas Mataram \\ Email: monicaayuchandra92@gmail.com
}

\begin{abstract}
Abstrak: Penelitian ini bertujuan untuk mengetahui pengaruh penerapan pembelajaran peta konsep terhadap pemahaman konsep koloid siswa kelas XI SMAN 2 Mataram tahun ajaran 2013/2014. Hasil belajar dalam penelitian ini meliputi hasil belajar dalam bentuk pengetahuan dan data hasil observasi aktifitas siswa sebagai data penunjang. Penelitian ini merupakan penelitian quasi experimental dengan populasi yaitu siswa kelas XI IPA 5 sampai dengan XI IPA 8 SMAN 2 Mataram tahun ajaran 2013/2014. Pengambilan sampel dilakukan dengan teknik random sampling untuk populasi dalam unit kelas. Kelas yang dijadikan sampel adalah kelas XI IPA 5 sebagai kelas kontrol yang menggunakan pembelajaran konvensional (ceramah) dan kelas XI IPA 6 sebagai kelas eksperimen yang menggunakan pembelajaran peta konsep. Data diperoleh dengan menggunakan pretest yang dilakukan di awal pembelajaran dan posttest yang dilaksanakan pada pertemuan akhir untuk menghitung tingkat kepahaman siswa melalui $\mathrm{N}$-gain. Uji stastistik yang digunakan untuk menguji hipotesis adalah uji Mann Whitney dengan pendekatan kurva normal Z yang dilakukan pada data $\mathrm{N}$-gain. Data kedua kelas menunjukkan bahwa tingkat kepahaman siswa kelas eksperimen dan kelas kontrol berada pada kategori sedang, yaitu 5.08. Hasil uji hipotesis N-gain pada taraf signifikan 5\% diperoleh $\mathrm{Z}_{\text {hitung }}(0,04)<\mathrm{Z}_{\text {tabel }}(1,96)$ yang berarti Ho pada penelitian ini diterima atau Ha ditolak. Hal ini menunjukkan bahwa penerapan pembelajaran peta konsep tidak berpengaruh lebih baik terhadap pemahaman konsep koloid siswa kelas XI SMAN 2 Mataram tahun ajaran 2013/2014.
\end{abstract}

Kata Kunci: Peta Konsep, Pemahaman Konsep, Koloid

\begin{abstract}
This study aims to determine the effect of the application of the concept map of learning students' to understanding the concept colloid class XI SMAN 2 Mataram academic year 2013/2014. Learning outcomes in this study include learning of knowledge and observation data from the student activities as supporting data. This study is a quasi experimental design, with the populations are students from class XI IPA 5 to XI IPA 8 of SMAN 2 Mataram academic year 2013/2014. Sampling was done with a random sampling technique to the population in the unit class. Sampled class is a class XI IPA 5 as a control class that uses the conventional learning (lectures) and class XI IPA 6 as an experimental class that uses the learning concept maps. Data obtained using a pretest conducted in early learning and posttests were carried out at the end of the meeting to calculate the level of student understanding through the N-gain. Statistical test is used to test the hypothesis is Mann Whitney test with normal curve approach is performed on the data $\mathrm{Z} \mathrm{N}$-gain. The data indicate that both classes of understanding students' grade level experimental and control classes in middle category, which is 5,08. The results of the $\mathrm{N}$-gain hypothesis test at significance level of 5\% was obtained Zhitung $(0,04)<$ Ztabel (1.96) which means that in this study received Ho or Ha rejected. This shows that the application of the learning concept maps have no effect on the better understanding of the concept colloid of class XI SMAN 2 Mataram academic year 2013/2014.
\end{abstract}

Keywords: Concept Maps, Concept Understanding, Colloid

\section{PENDAHULUAN}

Sains merupakan bagian dari kehidupan kita dan kehidupan kita merupakan bagian dari pembelajaran sains. Salah satu cabang dari pembelajaran sains adalah pembelajaran kimia. Kimia merupakan salah satu mata pelajaran yang kurang diminati oleh hampir sebagian besar siswa [1] (Suyanti, 2010). Sebagai mata pelajaran yang kurang diminati, guru kimia di sekolah menengah atas (SMA) harus berusaha lebih keras untuk memotivasi siswa agar siswa lebih tertarik untuk mempelajari konsep-konsep yang ada dalam kimia. Tanpa minat dan motivasi yang tinggi, konsep-konsep kimia akan sulit dipahami siswa dengan baik sehingga tujuan pembelajaran tidak tercapai.

Kesulitan yang dihadapi siswa dalam memahami mata pelajaran kimia sebagian besar karena kompleksitas materi yang dipelajari, yaitu materi yang berupa hitungan maupun materi pemahaman konsep. Kesalahan terbesar siswa dalam mempelajari suatu konsep adalah siswa cenderung untuk menghafal konsep tersebut, bukannya mencoba untuk memahami makna konsep tersebut serta kaitan antara konsep yang satu dengan konsep yang lain.

Salah satu faktor yang dapat mempengaruhi hasil belajar adalah metode mengajar. Metode ceramah dan diskusi (secara klasikal) merupakan metode yang cenderung digunakan oleh guru ketika mengajar di kelas. Metode pembelajaran ini digunakan oleh guru dikarenakan metode ini dianggap memiliki kelebihan, salah satunya dapat meminimalisir terjadinya miskonsepsi pada siswa. Akan tetapi, hasil belajar kimia siswa yang rendah dapat mengindikasikan bahwa perlu dilakukan perbaikan dalam pembelajaran di kelas, khususnya metode pembelajaran yang digunakan [2].

Sementara itu, kurikulum 2013 menuntut siswa untuk lebih aktif (melakukan observasi, bertanya, eksperimen, bernalar, dan mengkomunikasikan 
pengetahuan mereka setelah pembelajaran), lebih kreatif, inovatif, dan lebih produktif [3]. Oleh karena itu, metode konvensional dianggap kurang sesuai dengan kurikulum 2013. Salah satu upaya yang dapat dilakukan untuk mengatasi permasalahan tersebut di atas yaitu dengan menerapkan pembelajaran peta konsep.

Melalui pembelajaran ini, siswa dituntut untuk dapat menentukan, menyusun, dan menghubungkan sendiri konsep-konsep yang diberikan oleh guru, sehingga siswa akan menjadi aktif untuk mencari penyelesaian dari masalah yang dihadapi. Dengan menggunakan peta konsep, siswa dapat terlibat secara aktif dalam mengorganisir, menyusun, dan membuat peta konsep sesuai dengan pamahamannya pada saat proses pembelajaran berlangsung. Sehingga diharapkan aktifitas siswa di kelas menjadi lebih aktif. Selain itu, diharapkan pula pemahaman siswa terhadap suatu konsep tidak hanya berupa hafalan, tetapi bermakna, dan konsep tersebut dapat berdampak jangka panjang bagi siswa. Peta konsep sendiri merupakan bagan yang menunjukkan keterkaitan yang bermakna antar konsepkonsep yang relevan [4].

Peningkatan hasil belajar siswa dengan menggunakan pembelajaran peta konsep juga telah dibuktikan [5] pada konsep hewan Invertebrata pada siswa kelas X.1 SMA Negeri 8 Banjarmasin. Selain itu, penelitian [6] juga berhasil meningkatkan hasil belajar ikatan kimia siswa kelas X di SMA Negeri 1 Telaga dengan menerapkan strategi pembelajaran peta konsep.

Dimana, tujuan penelitian ini adalah untuk mengetahui pengaruh penerapan pembelajaran peta konsep terhadap pemahaman konsep koloid siswa kelas XI SMAN 2 Mataram tahun ajaran 2013/2014. Untuk mengarahkan penelitian ini, maka hipotesis yang diajukan adalah "penerapan pembelajaran peta konsep memberikan pengaruh yang lebih baik secara signifikan terhadap pemahaman konsep koloid siswa kelas XI SMAN 2 Mataram tahun ajaran 2013/2014”

\section{METODE PENELITIAN}

Penelitian ini dilaksanakan di SMAN 2 Mataram pada tanggal 19 Mei 2014 sampai dengan 3 Juni 2014, dengan design penelitian yang digunakan adalah desain eksperimen semu (quasi eperimental design). Populasi dalam penelitian ini adalah seluruh siswa kelas XI IPA SMAN 2 Mataram tahun pelajaran 2013/2014. Adapun teknik pengambilan sampel (sampling) yang digunakan dalam penelitian ini adalah sampel peluang (probability sampling), yaitu random sampling Pengambilan sampel dilakukan dengan teknik random sampling untuk populasi dalam unit kelas.

Data kemampuan awal kedua kelas sampel diperoleh melalui hasil pretest yang dilaksanakan sebelum kegiatan pembelajaran. Pembelajaran peta konsep diberikan untuk kelas eksperimen, sedangkan pada kelas kontrol menggunakan pembelajaran konvensional (metode ceramah). Pada akhir penelitian, untuk mendapatkan data akhir, dilakukan post-test terhadap kedua kelas.

Variabel bebas dalam penelitian ini adalah metode pembelajaran yang diterapkan pada kedua kelas sampel, yaitu metode peta konsep untuk kelas eksperimen dan metode konvensional untuk kelas sampel, sedangkan variabel terikatnya adalah pemahaman belajar siswa dalam ranah kognitif (hasil belajar).

Untuk mengukur tingkat kepahaman siswa dalam ranah kognitif digunakan instrumen hasil belajar berupa tes objektif dua tingkatan (two tier test). Tingkat pertama merupakan pilihan ganda yang berisi pilihan jawaban sebagai pengetahuan siswa, sedangkan tingkat kedua berisi pilihan alasan yang terkait dengan pilihan pertama [7].

Instrumen two tier test tersebut kemudian diuji reliabilitas dan validitasnya dengan rumus KR 20 untuk uji reliabilitas dan koreliasi point biserial untuk uji validitas. Hasil uji validitas dan reliabilitas menunjukkan bahwa terdapat 33 soal dengan kategori valid dengan reliabilitas tinggi $(0,080)$.

Teknik analisis data dilakukan pada data $\mathrm{N}$-gain untuk mengetahui kategori peningkatan yang dialami kedua kelas sampel. Skor gain ternormalisasi (N-Gain) yaitu perbandingan skor gain aktual dengan skor gain maksimum. Skor gain aktual yaitu selisih skor post-test dan skor pre-test, sedangkan skor gain maksimum yaitu skor gain tertinggi yang mungkin diperoleh siswa. Dengan menghitung skor gain ternormalisasi (N-Gain), maka tingkat perubahan kemampuan yang terjadi dalam diri siswa akan dapat diketahui [8]. Skor gain ternormalisasi dihitung menggunakan rumus:

$$
g=\frac{G}{G_{\text {maks }}}=\frac{S_{\text {post-test }}-S_{\text {pre-test }}}{S_{\text {maks }}-S_{\text {pre-test }}}
$$

Menurut Hake [8], hasil skor gain ternormalisasi dibagi menjadi tiga kategori.

\section{Tabel 1 Kriteria Gain Ternormalisasi}

\begin{tabular}{|c|c|}
\hline Persentase & Kriteria \\
\hline $\mathrm{g}<0,3$ & Rendah \\
\hline $0,7>\mathrm{g} \geq 0,3$ & Sedang \\
\hline $\mathrm{g} \geq 0,7$ & Tinggi \\
\hline
\end{tabular}

Setelah diperoleh data N-gain, dilakukan uji prasyarat (uji normalitas dan uji homogenitas) terhadap data tersebut dengan bertujuan untuk mengetahui teknik statistik yang digunakan. Oleh karena data yang diperoleh tidak terdistribusi normal dan homogen, maka digunakan statistik Mann Whitney dengan pendekatan kurva $\mathrm{Z}$ untuk menguji hipotesis pada penelitian ini [9] 


\section{HASIL PENELITIAN DAN PEMBAHASAN}

Pada Grafik 1 dapat dilihat bahwa nilai ratarata pretest kelas kontrol dan kelas eksperimen masih sangat rendah, yaitu masing-masing berturut-turut sebesar 9,08 dan 12,28. Hasil posttest kelas kontrol mengalami peningkatan sebesar 63,85, sedangkan kelas eksperimen yang belajar dengan menggunakan peta konsep mengalami peningkatan sebesar 63,45. Grafik 2 menunjukkan bahwa rata-rata nilai $\mathrm{N}$-gain secara keseluruhan kelas eksperimen dan kelas kontrol tidak berbeda secara signifikan, yang ditunjukkan

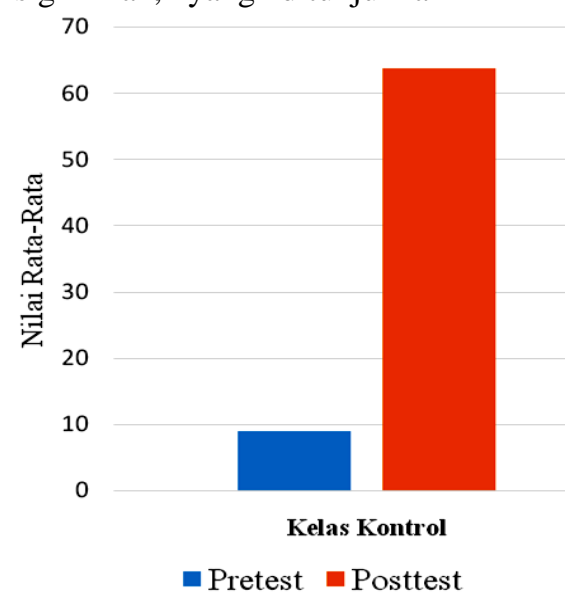

melalui rerata $\mathrm{N}$-gain kedua kelas yang sama, yaitu sebesar 5,08 (kategori sedang). Hal ini kemudian dibuktikan melalui uji-U Mann Whitney yang menunjukkan bahwa hipotesis nihil (Ho) diterima dan hipotesis alternatif (Ha) ditolak, yang artinya penerapan pembelajaran peta konsep tidak memberikan pengaruh yang lebih baik secara signifikan terhadap pemahaman konsep koloid siswa kelas XI SMAN 2 Mataram tahun ajaran 2013/2014.

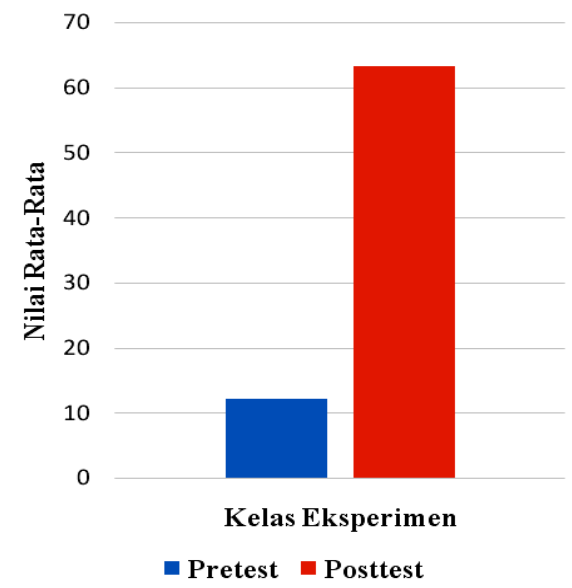

Grafik 1 Rata-Rata Nilai Pretest dan Posttest Kelas Eksperimen dan Kontrol

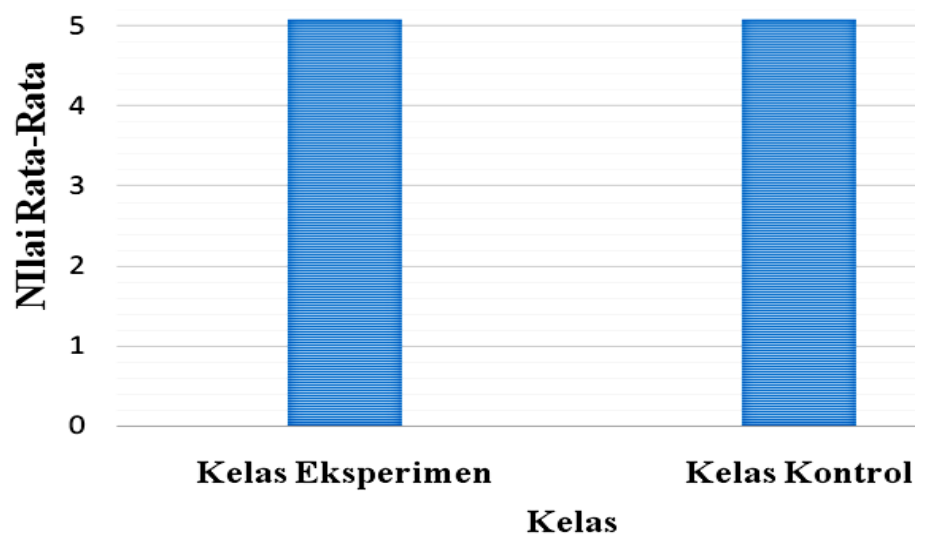

Grafik 2 Rata-Rata Nilai N-gain Kelas Eksperimen dan Kelas Kontrol

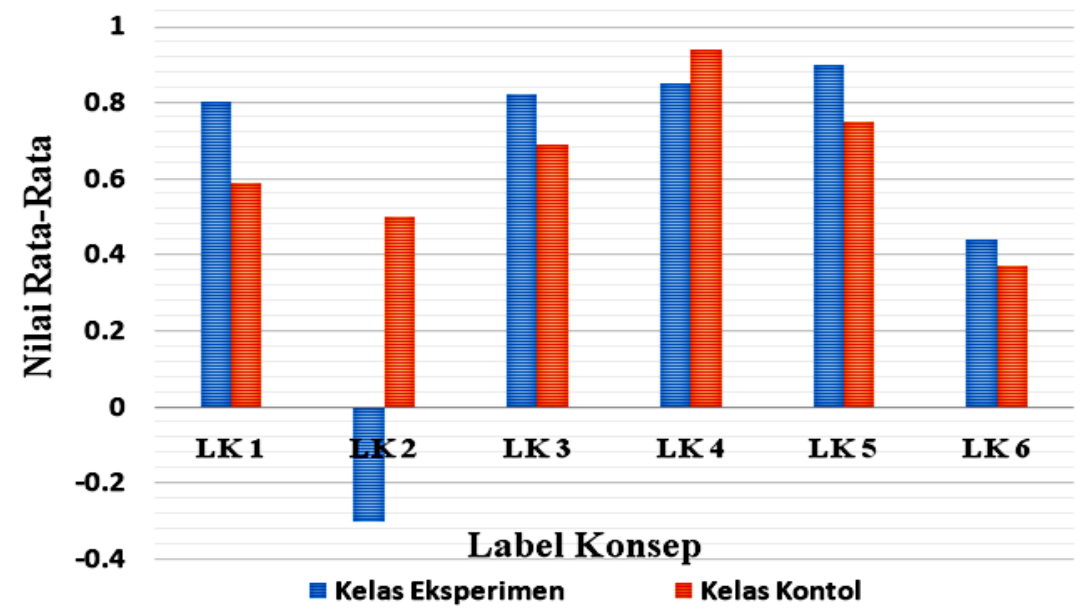

Grafik 3 Rata-Rata Nilai N-gain Perlabel Konsep 
Hal ini dapat dipengaruhi oleh beberapa faktor, diantaranya: 1) Kesiapan siswa, siswa belum terbiasa dengan penerapan pembelajaran peta konsep sehingga siswa masih membutuhkan penyesuaian saat proses pembelajaran. 2) Walaupun menyusun peta konsep cukup sederhana, tetapi dibutuhkan latihan yang berulang kali untuk membuat siswa terbiasa dalam menyusun suatu peta konsep tanpa hambatan sehingga proses pembelajaran menjadi lebih bermakna dan dapat ditanamkan dalam diri siswa. 3) Kemungkinan terjadinya kebocoran kisi-kisi soal yang akan diujikan. Hal ini dikarenakan perbedaan pelaksanaan posttest antara kedua kelas sampel.

Selanjutnya, dilakukan pula analisis N-gain perlabel konsep. Label Konsep 1 sampai dengan label konsep 6 disusun berdasarkan konsep-konsep esensial. pada pokok bahasan koloid sehingga nantinya konsepkonsep esensial tersebut dapat dilihat keterkaitannya melalui peta konsep. Berdasarkan Grafik 3 menunjukkan Label konsep 1 (sistem terdispersi), 3 (koloid), 4 (penggolongan sistem koloid), dan 6 (sifatsifat koloid) merupakan jenis konsep abstrak dengan contoh konkrit, label konsep 2 (campuran) merupakan jenis konsep berdasarkan prinsip, sedangkan label konsep 5 (proses pembuatan koloid) merupakan konsep konkrit. Perhitungan statistik yang digunakan untuk menguji hipotesis dari masing-masing lebel konsep sama dengan perhitungan statistik untuk mengolah data $\mathrm{N}$-gain secara keseluruhan, yaitu menggunakan uji-U Mann Whitney dikarenakan uji prasyarat menyatakan bahwa data tidak terdistribusi normal dan homogen.

Walaupun sama-sama merupakan konsep abstrak dengan contoh konkrit, label konsep 4 dan label konsep 6 memiliki tingkat pemahaman yang berbeda untuk siswa pada kelas kontrol. Label konsep 4 (penggolongan sistem koloid) merupakan label konsep dengan tingkat pemahaman tertinggi, sedangkan kebalikannya yaitu label konsep 6 (sifatsifat koloid) merupakan label konsep dengan tingkat pemahaman paling rendah. Materi sifat-sifat koloid sendiri merupakan materi dengan kompleksitas yang lebih tinggi dibandingkan dengan materi penggolongan sistem koloid. Hal ini dapat menyebabkan tingkat kesukaran siswa dalam memahami materi sifat-sifat koloid tentu lebih sulit dibandingkan pada saat memahami materi penggolongan sistem koloid. Tingkat kompleksitas materi sifat-sifat koloid ini juga menyebabkan label konsep 6 merupakan label konsep dengan tingkat pemahaman konsep yang tidak jauh berbeda antara kelas eksperimen dengan kelas kontrol. Sehingga dapat dikatakan bahwa tingkat pemahaman siswa baik siswa di kelas eksperimen dan kelas kontrol masih kurang pada materi sifat-sifat koloid.

Untuk kelas eksperimen, peningkatan pemahaman konsep siswa tertinggi terdapat pada label konsep 5 (proses pembuatan koloid), dengan jenis konsep konkrit. Pada label ini siswa tidak terlalu mengalami banyak kendala selama proses pembelajaran dikarenakan siswa dapat dengan mudah menentukan contoh dan noncontoh dari label tersebut. Sedangkan, peningkatan label konsep paling rendah pada kelas eksperimen ditunjukkan pada label konsep 2 (campuran), dengan jenis konsep berdasarkan prinsip. Label konsep ini juga sekaligus merupakan label konsep dengan tingkat perbedaan yang cukup signifikan antara kelas eksperimen dan kelas kontrol, dimana nilai rata-rata siswa untuk label konsep 2 pada kelas eksperimen berada pada kategori rendah yaitu sebesar -0,3, sedangkan nilai rata-rata siswa untuk label konsep 2 pada kelas kontrol berada pada kategori sedang $(0,5)$. Hal ini menunjukkan bahwa pada label konsep ini, pembelajaran dengan menggunakan peta konsep pada kelas eksperimen tidak terlalu menunjukkan dampak yang berarti.

Label konsep 2 yaitu konsep campuran merupakan jenis konsep berdasarkan prinsip, dimana berdasarkan prinsip ini siswa dapat membedakan prinsip yang mencirikan konsep larutan, suspensi, dan koloid. Pembelajaran dengan metode peta konsep menuntut siswa untuk menyusun sendiri pemahamannya tentang konsep yang dipelajari. Hal ini dapat menyebabkan kesalahan pada saat siswa menyusun peta konsep dan menjadi faktor penyebab mengapa nilai $\mathrm{N}$-gain untuk label konsep ini berada pada kategori rendah pada kelas eksperimen. Sedangkan, tingginya tingkat pemahaman siswa kelas kontrol pada label konsep ini dapat disebabkan karena siswa kelas kontrol mendapatkan penekanan terhadap materi campuran melalui metode konvensional (ceramah) selama proses pembelajaran

\section{KESIMPULAN DAN SARAN}

Berdasarkan data hasil penelitian dan pembahasan, dapat disimpulkan bahwa penerapan pembelajaran peta konsep tidak memberikan pengaruh yang lebih baik secara signifikan terhadap pemahaman konsep koloid siswa kelas XI SMAN 2 Mataram tahun ajaran 2013/2014. Oleh karena penerapan pembelajaran peta konsep tidak mampu meningkatkan hasil belajar siswa pada materi koloid, yang terlihat dari nilai rata-rata siswa yang masih di bawah KKM, maka perlu dilakukan penelitian lanjutan dengan menerapkan metode yang lain pada pokok bahasan ini

\section{DAFTAR PUSTAKA}

[1] Suyanti, R. D. 2010. Strategi Pembelajaran Kimia. Yogyakarta: Graha Ilmu.

[2] Slameto. 2010. Belajar dan Faktor-Faktor yang Mempengaruhinya. Jakarta: Rineka Cipta.

[3] Depdikbud. 2013. Kurikulum 2013. Jakarta

[4] Indahwati, T. S. J. 2012. Penerapan Model Inquiry Training melalui Teknik Peta Konsep dan Teknik Puzzle Ditinjau dari Tingkat Keberagaman Aktivitas Belajar dan Kemampuan Memori. Jurnal Inkuiri. 1 (3). $258-265$

[5] Rezeki, A., dkk. 2011. Penggunaan Peta Konsep Untuk Meningkatkan Pemahaman Siswa Kelas X 1 SMA Negeri 8 Banjarmasin Pada Konsep Hewan Invertebrata. Jurnal Wahana-Bio. 6. 20-39. 
[6] Ismail, M. 2013. Meningkatkan Hasil Belajar Ikatan Kimia dengan Menerapkan Strategi Pembelajaran Peta Konsep pada Siswa Kelas $X$ di SMA Negeri Telaga. Jurnal Entropi. 3 (1). $521-529$.

[7] Adodo. 2013. "Effects of Two-Tier Multiple Choice Diagnostic Assessment Items on Students' Learning Outcome in Basic Science Technology (BST)". Academic Journals of Interdiciplinary Studies. 2 (2). 201-210.

[8] Hake, R.R. 1998. Interactive-Engagement Versus Traditional Methods: A Six-Thousand Student Survey of Mechanics Test Data for Introductory Physics Courses. American Association of Physics Teachers. 66 (1). 6474

[9] Sugiyono. 2013. Statistik untuk Penelitian Pendidikan. Bandung: Alfabeta 